\title{
ANALISIS KEMAMPUAN BERPIKIR KRITIS MATEMATIS SISWA DALAM LEARNING CYCLE 7E BERDASARKAN GAYA BELAJAR
}

\author{
Rosmaiyadi \\ STKIP Singkawang \\ Email: rosmaiyadialong@gmail.com
}

\begin{abstract}
This research aims to test the effectiveness of Learning Cycle 7E”, the influence of learning style against the students ability of critical thinking, the best learning style of the student is critical thinking ability and description of students' mathematical critical thinking ability in each learning style. The methods used in this research was Mixed Design Model; the Sequential Explanatory Method. The subject of this research is grade VIII. The research instrument used is the TKBKM, learning style questionnaire and interview guidelines. The effectiveness of Learning Cycle $7 E$ it can be seen from the aspect of completeness, obtained the result that the proportion of students who got a value KBKM greater than or equal with KKM=70 have exceeded $75 \%$, while the average difference test of experiments class and control class were $t$ - count $^{-}=6,497>t$ ${ }_{\text {tabel }}=1,671$. This shows that the average students' mathematical critical thinking ability taught by Learning Cycle 7E more than average than students' mathematical critical thinking ability taught with conventional learning. Learning styles affect the students' mathematical critical thinking ability, this is retrieved based on the test results of the Kruskal Wallis with Asym value sig is $0.046<0.05$. The visual learning style has the best ability of mathematical critical thinking. Each learning style has advantages and disadvantages on aspects of ability of critical thinking mathematically, thus causing each learning style has differences the ability of critical thinking mathematically too.
\end{abstract}

Keywords: critical thinking, learning cycle 7E, learning style

\section{PENDAHULUAN}

Matematika merupakan disiplin ilmu yang mempunyai sifat khas. Kekhasan itu berkenaan dengan ide-ide atau konsep-konsep abstrak yang tersusun secara hirarkis. Mata pelajaran matematika perlu diberikan kepada semua peserta didik mulai dari sekolah dasar, untuk membekali peserta didik dengan kemampuan berpikir logis, analitis, sistematis, kritis, inovatif dan kreatif, serta kemampuan bekerjasama. Kompetensi tersebut diperlukan agar peserta didik dapat memiliki kemampuan memperoleh, mengelola, dan memanfaatkan informasi untuk hidup lebih baik pada keadaan yang selalu berubah, tidak pasti, dan sangat kompetitif. Dalam melaksanakan pembelajaran matematika, diharapkan bahwa peserta didik harus dapat merasakan kegunaan belajar matematika.

Pembelajaran pada kurikulum 2013 memiliki tujuan untuk mencapai kemampuan berpikir tingkat tinggi atau High Order Thingking (HOT) sejak dini. Berpikir kritis dan berpikir kreatif merupakan perwujudan dari HOT. Berbagai definisi mengenai kemampuan berpikir kritis telah banyak dicetuskan oleh para ahli. Sukmadinata (2004) menyatakan berpikir kritis adalah suatu kecakapan nalar secara teratur, kecakapan sistematis dalam menilai, memecahkan masalah, menarik 
keputusan, memberikan keyakinan, menganalisis asumsi, dan pencarian ilmiah. Desmita (2012) mengutip pendapat yang dikemukakan oleh Beyer yaitu berpikir kritis adalah kumpulan operasi-operasi spesifik yang mungkin dapat digunakan satu persatu atau dalam banyak kombinasi atau urutan dan setiap operasi berpikir kritis tersebut memuat analisis dan evaluasi. Santrock menjelaskan bahwa berpikir kritis adalah pemikiran reflektif dan produktif serta melibatkan evaluasi bukti. Glazer (2001) mendefinisikan bahwa berpikir kritis dalam matematika adalah kemampuan dan disposisi untuk menggabungkan pengetahuan sebelumnya, penalaran matematika, dan strategi kognitif untuk menggeneralisasi, membuktikan, atau mengevaluasi situasi matematis asing secara reflektif.

Hasil penelitian Rochmad (2013) diketahui bahwa keterampilan guru dan siswa dalam berpikir kreatif dalam kategori rendah. Keterampilan berpikir kreatif siswa tergolong rendah diindikasikan dari kemampuan berpikir kritis siswa rendah. Sebagaimana pendapat Noddings yang telah dikutip oleh Saurino (2008) menyatakan banyak siswa yang kurang kritis, ketika para siswa diberikan soal-soal yang memuat berpikir kritis atau memecahkan masalah siswa sering melewatkan dan bahkan tidak mengerjakannya. Hal ini sesuai dengan hasil studi awal pada SMP Negeri 19 Singkawang. Pada proses pembelajaran ketika siswa diberikan latihan soal-soal non rutin, sebagian besar siswa mengalami kesulitan dan tidak mengerjakan soal ketika dihadapkan pada pemecahan masalah matematika. Kesulitan tersebut dikarenakan siswa masih belum terbiasa dengan soal-soal non rutin dan juga karena kemampuan berpikir kritis siwa masih rendah. Hal ini diketahui dari pekerjaan siswa pada ulangan harian materi geometri yaitu materi Bangun Ruang Sisi Datar. Pada soal yang berbentuk pemecahan masalah siswa hanya dapat menuliskan hal-hal yang diketahui pada soal, tanpa menyertakan rencana penyelesaian dan penyelesaiannya. Mereka cenderung mengerjakan soal tersebut hanya dengan konsep yang diajarkan guru saja tanpa menggunakan atau menghubungkan konsep-konsep yang telah dipelajari sebelumnya. Jadi ketika menjawab soal mereka selalu menggunakan rumusrumus bangun datar yang dipelajari saja.

Usaha meningkatkan kemampuan berpikir kritis matematis memerlukan adanya pembenahan dalam proses pembelajaran. Oleh karena itu perlu diupayakan suatu pembelajaran dengan model atau metode tertentu yang dapat meningkatkan aktivitas, motivasi dan kemampuan berpikir kritis peserta didik sehingga belajar peserta didik dapat menjadi bermakna. Model pembelajaran yang mempunyai karakteristik tersebut diantaranya adalah model pembelajaran Learning Cycle $7 E$ yang terdiri dari 7 tahapan (Eisenkraft, 2003) yaitu: Elicit, Engage, Explore, Explain, Elaborate, Evaluate, dan Extend.

Dalam mempelajari materi di dalam kelas, setiap siswa memiliki karakteristik yang berbeda antara siswa yang satu dan yang lainnya. Salah satu karakteristik siswa yang perlu diperhatikan pada saat proses belajar mengajar adalah gaya belajar. Nasution (2003) mendefinisikan gaya belajar atau learning style adalah cara yang konsisten yang dilakukan oleh seorang siswa dalam menangkap stimulus atau informasi, cara mengingat, berpikir, dan memecahkan soal. De Porter dan Hernacki (2013) menyatakan gaya belajar merupakan suatu kombinasi dari bagaimana ia menyerap, dan kemudian 
mengatur serta mengolah informasi. Dunn dan Griggs (2000) menjelaskan bahwa gaya belajar merupakan kumpulan karakteristik pribadi yang membuat suatu pembelajaran efektif untuk beberapa orang dan tidak efektif untuk orang lain. Ilmiyah dan Masriyah (2013) mengemukakan bahwa gaya belajar merupakan cara berbeda yang dimiliki setiap individu untuk memproses, mendalami, dan mempelajari informasi dengan mudah.

De Porter dan Hernacki (2013), menyatakan ada tiga jenis gaya belajar yaitu: 1) Visual, belajar dengan cara melihat; 2) Auditorial, belajar dengan cara mendengarkan; dan 3) Kinestetik, belajar dengan cara bergerak, bekerja dan menyentuh. Setiap siswa pasti memiliki gaya belajar yang berbedabeda. Sehingga dalam mengikuti pembelajaran mereka menggunakan cara yang berbeda-beda untuk memahami materi yang mereka pelajari.

Proses pelaksanaan pembelajaran di kelas sebaiknya guru memperhatikan aspek gaya belajar siswa. Hal ini sesuai dengan pendapat yang dikemukakan oleh Karza (2013) bahwa guru harus mengajar sesuai dengan bentuk dan gaya belajar yang dimiliki oleh siswanya. Jika guru melaksanakan pembelajaran dengan memperhatikan aspek gaya belajar, maka pembelajaran di kelas akan lebih menyenangkan dan siswa akan lebih mudah memahami apa yang mereka pelajari. Seperti yang dikutip oleh Mubarik (2013), hasil penelitian Akyun menyatakan bahwa guru sebagai pihak yang terkait langsung dengan masalah pendidikan dan langsung berinteraksi dengan siswa berkewajiban untuk mengkaji dan menyelidiki gaya belajar siswa yang dapat mempengaruhi hasil belajar matematika siswa. Hal senada diungkapkan oleh Indarto (2012) bahwa siswa yang mengenali gaya belajarnya sendiri akan membantu memahami materi yang diberikan guru sehingga mudah memproses materi.

Melalui pembelajaran Learning Cycle $7 E$ diharapkan siswa terbiasa dengan cara berpikir kritis, sehingga nantinya dapat meningkatkan kemampuan berpikir kritis matematisnya untuk semua siswa walaupun masing-masing siswa memiliki gaya belajarnya sendiri.

Hasil penelitian Bhatti dan Bart (2013) menyatakan bahwa gaya belajar dan gender mempengaruhi prestasi akademik. Mappeasse (2009) mengutip pendapat Gie bahwa cara belajar yang baik akan menyebabkan berhasilnya belajar, sebaliknya cara belajar yang buruk akan menyebabkan kurang berhasilnya atau gagalnya belajar. Hal yang sama juga diungkapkan oleh Indarto dalam Mubarik (2013) penelitiannya yang menyimpulkan bahwa terdapat pengaruh yang positif dan signifikan antara gaya belajar dengan prestasi belajar. Hasil penelitian Gappi (2013) memiliki kesimpulan yang berbeda yaitu menyatakan bahwa tidak ada korelasi signifikan antara prestasi akademik dan gaya belajar siswa. Hal yang sama juga diungkapkan oleh Adnan (2013) hasil penelitiannya menyatakan bahwa hubungan antara gaya belajar dengan kemampuan matematika lemah. Berdasarkan beberapa hasil penelitian ini peneliti tertarik untuk meneliti bagaimana hubungan antara gaya belajar dengan dengan prestasi akademik dalam matematika dalam hal ini adalah kemampuan berpikir kritis matematis serta mendekripsikan bagaimana kemampuan berpikir kritis matematis siswa untuk masing-masing siswa dengan gaya belajar yang berbeda.

Rumusan masalah dalam penelitian ini adalah (1) Apakah model pembelajaran Learning Cycle $7 E$ efektif 
dalam meningkatkan kemampuan berpikir kritis matematis siswa; (2) Apakah terdapat pengaruh gaya belajar siswa terhadap kemampuan berpikir kritis matematisnya pada pembelajaran dengan model Learning Cycle 7E; (3) Gaya belajar manakah yang paling baik kemampuan berpikir kritisnya pada pembelajaran dengan model Learning Cycle 7E; (4) Bagaimanakah kemampuan berpikir kritis matematis siswa dengan gaya belajar visual pada pembelajaran dengan model Learning Cycle 7E; (5) Bagaimanakah kemampuan berpikir kritis matematis siswa dengan gaya belajar auditorial pada pembelajaran dengan model Learning Cycle 7E; (6) Bagaimanakah kemampuan berpikir kritis matematis siswa dengan gaya belajar kinestetik pada pembelajaran dengan model Learning Cycle $7 E$.

\section{METODE PENELITIAN}

Jenis penelitian ini adalah penelitian kombinasi kualitatif dan kuantitatif atau Mixed Method. Model kombinasi yang digunakan dalam penelitian ini adalah tipe Sequantial Explanatory Design. Model penelitian Sequential Explonatory Design dicirikan dengan melakukan pengumpulan data dan analisis data kuantitatif pada tahap pertama, dan diikuti dengan pengumpulan dan analisis data kualitatif pada tahap kedua, guna memperkuat hasil penelitian kuantitatif yang dilakukan pada tahap pertama (Sugiyono, 2011). Dalam penelitian ini, penelitian kualitatif sebagai metode primer sedangkan penelitian kuantitatif sebagai metode sekunder.

Subjek penelitian adalah siswa kelas VIII SMP Negeri 19 Singkawang tahun pelajaran 2014-2015. Teknik pengumpulan data yang digunakan dalam penelitian ini adalah teknik tes, kuesioner/angket dan wawancara. Teknik kuesioner/angket digunakan untuk mendapatkan data gaya belajar siswa, teknik tes digunakan untuk mendapatkan data kemampuan berpikir kritis matematis siswa dengan menggunakan tes kemampuan berpikir kritis matematis, untuk sedangkan teknik wawancara untuk memperoleh data lebih dalam dan akurat bagaimana kemampuan berpikir kritis matematis siswa. Analisis kuantitatif dilakukan untuk menguji keefektifan pembelajaran yang diperoleh dari ketuntasan kemampuan berpikir kritis matematis siswa, dan uji banding rataan kemampuan berpikir kritis matematis kelas eksperimen dan kontrol. Untuk menguji pengaruh gaya belajar terhadap kemampuan berpikir kritis matematis siswa menggunakan uji Kruskal Wallis. Sedangkan untuk mengetahui gaya belajar yang memiliki kemampuan berpikir kritis yang paling baik dengan melihat nilai rata-rata tertinggi dari tes kemampuan berpikir kritis matematis. Untuk memperdalam hasil penelitian dilakukan wawancara pada masingmasing kelompok gaya belajar sebagai penelitian kualitatifnya untuk memperoleh deskripsi yang lebih rinci mengenai kemampuan berpikir kritis matematisnya.

\section{HASIL PENELITIAN DAN PEMBAHASAN}

Berdasarkan analisis data penelitian, diperoleh bahwa kriteria keefektifan pembelajaran model Learning Cycle $7 E$ yang pertama telah terpenuhi, hal ini diperoleh dari hasil tes kemampuan berpikir kritis matematis siswa pada pembelajaran model Learning Cycle $7 E$ diperoleh hasil bahwa siswa-siswa telah mencapai ketuntasan individual dan ketuntasan klasikal. Kriteria keefektifan yang kedua diperoleh dari uji perbedaan 
rerata kemampuan berpikir kritis matematis. Diperoleh hasil bahwa kemampuan berpikir kritis matematis siswa yang diajarkan pembelajaran model Learning Cycle 7E lebih baik yakni sebesar 75,81 jika dibandingkan dengan kemampuan berpikir kritis matematis siswa pada kelas kontrol yang hanya sebesar 64,92 . Berdasarkan data tersebut maka kriteria keefektifan yang kedua yaitu uji beda dua rata-rata terpenuhi.

Hasil penelitian ini sejalan dengan hasil penelitian Mecit (2006) dimana hasil penelitian adalah bahwa pembelajaran model Learning Cycle $7 E$ menyebabkan terjadinya kemajuan yang signifikan terhadap kemampuan berpikir kritis siswa. Hasil penelitian Siribunan dan Tayraukham (2009) juga menunjukkan hasil bahwa kemampuan berpikir kritis lebih tinggi dari pada siswa yang belajar dengan model konvensional. Secara umum, melalui pembelajaran matematika model Learning Cycle $7 E$ dapat meningkatkan kemampuan berpikir kritis matematis siswa.

Pembelajaran model Learning Cycle $7 E$ mampu meningkatkan kemampuan berpikir kritis matematis karena dalam menumbuhkan kemampuan berpikir kritis matematis siswa dibutuhkan pembelajaran yang bersifat konstruktif, interaktif dan reflektif dan salah satu pembelajaran yang memiliki sifat tersebut adalah pembelajaran model Learning Cycle 7E. Hal ini sejalan dengan pendapat Treffers, de Moor dan Feijs (Goffree \& Dolk, 1995) mengatakan bahwa ada tiga pilar proses pembelajaran matematika dalam membangun pola pikir matematis dan kecerdasan interpersonal siswa, yaitu pembelajaran yang bersifat konstruktif, interaktif dan reflektif. Pembelajaran model Learning Cycle $7 E$ bersifat konstruktif karena dalam proses pembelajarannya pengetahuan dibangun dari pengetahuan siswa itu sendiri dan melalui permasalahan yang bersifat kontekstual. Pembelajaran model Learning Cycle $7 E$ menerapkan sifat interaktif dalam proses pembelajaran karena siswa yang lebih berperan penting dalam proses pembelajaran melalui diskusi serta presentasi dan guru hanya sebagai fasilitator saja.

Berdasarkan hasil analisis data terhadap kuesioner gaya belajar siswa didapat bahwa dari 28 orang siswa di kelas yang pembelajarannya menggunakan model pembelajaran Learning Cycle $7 E$ ternyata 8 orang memiliki gaya belajar visual, 9 orang memiliki gaya belajar auditorial dan 11 orang siswa memiliki gaya belajar kinestetik.

Uji Kruskal Wallis dilakukan untuk menguji pengaruh gaya belajar terhadap kemampuan berpikir kritis matematis. Alasan penggunaan Uji Kruskal Wallis dalam penelitian ini adalah karena jumlah sampel masingmasing kelompok gaya belajar kecil, sehingga uji yang digunakan menggunakan uji non parametrik, dalam hal ini menggunakan Uji Kruskal Wallis. Hasil dari uji Kruskal Wallis menunjukkan bahwa masing-masing kelompok gaya belajar memiliki perbedaan kemampuan berpikir kritisnya. Oleh karena itu dapat disimpulkan bahwa gaya belajar mempengaruhi kemampuan berpikir kritis matematis siswa.

Hasil penelitian ini senada dengan hasil penelitian Bhatti \& Bart (2013) yang menyatakan bahwa gaya belajar dan gender mempengaruhi prestasi akademik, begitu pula hasil penelitian Mubarik (2013) yang mengungkapkan bahwa terdapat pengaruh positif dan signifikan antara gaya belajar dengan prestasi belajar. 
Nilai rata-rata kemampuan berpikir kritis matematis siswa berbeda antara masing-masing kelompok gaya belajar. Kelompok siswa dengan gaya belajar visual memiliki kemampuan berpikir kritis matematis yang paling baik jika dibandingkan kelompok siswa bergaya belajar auditorial dan kinestetik. Sementara itu kemampuan berpikir kritis matematis siswa dengan gaya belajar auditorial lebih baik daripada kelompok siswa dengan gaya belajar kinestetik.

Hasil penelitian menunjukkan bahwa rata-rata kemampuan berpikir kritis matematis siswa berbeda ditiap kelompok gaya belajarnya. Hasil penelitian juga menunjukkan bahwa setiap kelompok gaya belajar memiliki kelebihan dan kekurangan dalam kemampuan berpikir kritis matematis di sapek-aspek tertentu, namun berdasarkan nilai rata-rata kemampuan berpikir kritis kelompok gaya belajar visual lebih baik dibandingkan kelompok gaya belajar auditorial, sedangkan kelompok gaya belajar auditorial memiliki kemampuan yang lebih baik daripada kelompok gaya belajar kinestetik.

Kemampuan berpikir kritis dimasing-masing kelompok gaya belajar berbeda, hal ini dikarenakan masing-masing gaya belajar memiliki kelebihan dan kekurangan dimasingmasing aspek kemampuan berpikir kritis matematis. Masing-masing gaya belajar memiliki cara masing-masing dalam menyerap dan mengolah informasi yang ia peroleh. Begitu pula halnya dengan aspek-aspek kemampuan berpikir kritis, masing-masing aspek memiliki kriteria-kriteria tersendiri pada soalnya, sehingga jika kriteria aspek berpikir kritis tersebut sejalan dengan cara seseorang dalam menyerap dan mengolah informasi, maka kemampuan siswa pada aspek tersebut akan sangat baik, begitu pula sebaliknya. Hal ini senada dengan pendapat De Porter \& Mike Hernacki (2013) bahwa gaya belajar adalah kombinasi dari bagaimana anda menyerap, mengatur dan mengolah informasi.

\section{KESIMPULAN DAN SARAN}

Berdasarkan analisis hasil penelitian, kemampuan berpikir kritis matematis siswa dalam Learning Cycle $7 E$ berdasarkan gaya belajar di SMP Negeri 19 Singkawang dapat disimpulkan, (1) Pembelajaran model Learning Cycle $7 E$ efektif dalam meningkatkan kemampuan berpikir kritis matematis; (2) Gaya belajar mempengaruhi kemampuan berpikir kritis matematis siswa dalam pembelajaran model Learning Cycle $7 E$; (3) Kelompok siswa dengan gaya belajar visual memiliki kemampuan berpikir kritis matematis yang paling baik dibandingkan siswa kelompok gaya belajar auditorial dan kinestetik; (4) Kelompok siswa yang memiliki gaya belajar visual memiliki kemampuan berpikir kritis matematis yang paling baik pada aspek asumsi dan menafsirkan informasi. Sedangkan pada aspek penarikan kesimpulan, deduksi dan penilaian argumen memiliki kemampuan yang sudah cukup baik; (5) Kelompok siswa yang memiliki gaya belajar auditorial memiliki kemampuan berpikir kritis matematis yang paling baik pada aspek penarikan kesimpulan. Untuk aspek deduksi menafsirkan informasi dan penilaian argumen sudah cukup baik, namun pada aspek asumsi paling jelek; (6) Kelompok siswa yang memiliki gaya belajar kinestetik memiliki kemampuan berpikir kritis matematis yang paling baik pada aspek deduksi dan penilaian argumen. Untuk aspek penarikan kesimpulan dan menafsirkan informasi sudah cukup 
baik, namun pada aspek asumsi paling jelek.

Berdasarkan simpulan penelitian, peneliti mengemukakan saran sebagai berikut : (1) Deskripsi kemampuan berpikir kritis matematis ditinjau berdasarkan gaya belajar telah diperoleh, bagi peneliti selanjutnya agar dapat mengadakan penelitian untuk memperoleh deskripsi kemampuan lainnya dalam matematika jika ditinjau berdasarkan gaya belajar; (2) Gaya belajar mempengaruhi kemampuan berpikir kritis matematis, maka disarankan kepada siswa untuk tahu dan memahami gaya belajar masing-masing sehingga dalam proses pembelajaran memperoleh hasil yang baik; (3) Kepada guru matematika disarankan untuk meningkatkan kemampuan berpikir kritis matematis siswasiswanya dengan menggunakan model pembelajaran yang cocok untuk semua gaya belajar siswa, karena kemampuan berpikir kritis matematis yang baik merupakan dasar bagi seseorang untuk memiliki kemampuan pemecahan masalah yang merupakan kemampuan tinggi dalam matematika.

\section{DAFTAR PUSTAKA}

Adnan, M. 2013. Learning Style and Mathematics Achievement among High Performance School Students. World Applied Sciences Journal, 28 (3): 392-399, 2013. Malaysia : IDOSI Publications

Bhatti, R. \& Bart, W.M. 2013. On the Effect of Learning Style on Scholastic Achievement. Journal Current Issues in Education, Vol.16 No.2 USA : Arizona State University

\begin{tabular}{crr} 
Desmita. 2012. & \multicolumn{2}{r}{ Psikologi } \\
Perkembangan & Peserta & Didik. \\
Bandung : & PT. & Remaja \\
Rosdakarya. & &
\end{tabular}

DePorter, B \& Hernacki, M. 2013. Quantum Learning membiasakan Belajar Nyaman dan Menyenangkan. Bandung: Kaifa.

Dunn, R \& Griggs, S.A. 2000. Practical Approaches to Using Learning Style in Higher Education. USA : Greenwood Publishing.

Eisenkraft, A. (2003). Expanding the 5E model : A Proposed 7E Model Emphasizes " Tranfer of learning"and the importance of Eliciting Prior Understanding. Journal the Science Teacher, volume 70. Hal 58-59.

Gappi, L. L. 2013. Relationships between Learning Style Preferences and Academic Performance of Students. International Journal of Educational Research and Technology, Volume 4 [2] June 2013: $70-76$

Glazer, E. 2001. Using Internet Primary Sources to Teach Critical Teaching Skills in Mathematics. London : Greenword Press.

Goffree, F \& Dolk, M. 1995. Standards for Mathematics Education. Freudenthal Institute: SLO/NVORWO.

Ilmiyah, S \& Masriyah. 2013. Profil Pemecahan Masalah Matematika Siswa SMP Pada Materi Pecahan Ditinjau Dari Gaya Belajar, (online), Jurnal MATHEdenusa, vol. 2, no 1 , (http://ejournal.unesa.ac.id/, Diakses Tanggal 2 Februari 2015).

Indarto, Danang. 2012. Pengaruh Gaya Belajar dan Motivasi Berprestasi Siswa terhadap Prestasi Belajar Praktik Instalasi Listrik Di Smk Negeri 2 Yogyakarta. Lumbung Pustaka Universitas Negeri Yogyakarta. 
Karza, P., Rivaie,W., \& Ibrahim, M.Y. 2013. Gaya Belajar Siswa Pada Mata Pelajaran Sosiologi Kelas XI di SMA Negeri 1 Sungai Raya Kepulauan, Jurnal Pendidikan dan Pembelajaran vol. 2, no 2 (http://jurnal.untan.ac.id/, Diakses Tanggal 26 Desember 2014).

Mappeasse, M. Y. 2009. Pengaruh Cara dan Motivasi Belajar Terhadap Hasil Belajar Programable Logic Controller (PLC) Siswa Kelas III Jurusan Listrik SMK Negeri 5 Makassar. Jurnal Media Edukasi Pendidikan Teknologi dan Kejuruan, vol. 1, no 2. (http://www.ft-unm.net, Diakses Tanggal 10 Desember 2014).

Mecit, Q. 2006. "The Effect Of 7E Learning Cycle Model On The Improvement Offifth Grade Students' Critical Thinking Skills". Thesis : Department of Secondary Science and Mathematics Education, MIDDLE EAST TECHNICAL UNIVERSITY.

Mubarik. 2013. Profil Pemecahan Masalah Siswa Auditorial Kelas $X$ SLTA Pada Materi Sistem Persamaan Linear Dua Variabel. Makalah. Seminar Nasional Sains dan Matematika II Jurusan Pendidikan MIPA FKIP UNTAD 2013
Nasution, S. 2003. Berbagai Pendekatan Dalam Proses Belajar dan Mengajar. Jakarta: Bumi Aksara

Rochmad. 2013. Keterampilan Berpikir Kritis \& Kreatif Dalam Pembelajaran Matematika. Makalah. Makalah disajikan dalam Seminar Nasional Matematika VII tahun 2013 di Universitas Negeri Semarang. Semarang, 26 Oktober 2013.

Saurino, D. R. 2008. Concept Journaling to Increase Critical Thinking Dispositions and Problem Solving Skills in Adult Education. The Journal of Human Resource and Adult Learning. Vol. 4(1), 170-178

Siribunam, R \& Tayraukham, S. 2009. "Effects of 7-E, KWL and Conventional Instruction on Analytical Thinking, Learning Achievement and Attitudes toward Chemistry Learning". Journal of Social Sciences, Vol 5(4): 279-282.

Sukmadinata, N. 2004. Kurikulum \& Pembelajaran Kompetensi. Bandung : PT Remaja Rosdakarya

Sugiyono. 2011. Metode Penelitian Kuantitatif, kualitatif dan $R \& D$. Bandung: Alfabeta. 